\title{
北海道の国営農業農村整備事業に対する受益農家の評価
}

Study of Beneficiary Farmers' Evaluation on the Government-Operated Agriculture and Rural Development Project in Hokkaido

\author{
森 繁“山本 忠男**井上 京** 長澤 徹明*** \\ Mori Shigeru" Yamamoto Tadao ${ }^{* *}$ Inoue Takashi** Nagasawa Tetuaki** \\ (*北海道大学大学院農学院 ${ }^{* *}$ 北海道大学大学院農学研究院 ${ }^{* * *}$ 北海道大学名誉教授)
}

("Graduate School of Agriculture, Hokkaido University "Research Faculty of Agriculture, Hokkaido University ***Professor Emeritus, Hokkaido University)

I はじめに

北海道の農業は,その高い食料自給率(平成20年度カ口 リーベースで210\%)"が示唆するように，わが国の食料 基地として重要な位㯰を占めている。しかしながら，そ の基盤を整備する農業農村整備事業費は平成22年度以降 大きく减少し2，事業の計画的な実施が危惧されている。 また, 国と地方の役割分担から直轄事業, 補助事業などの 制度の見直し，さらには道州制の検討など実施体制のあ

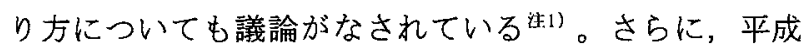
24年度時点で政府は環太平洋連携協定（T P P）に参加 すべく協議を開始しようとしており，わが国の農業の方 向自体が不透明な状況にある。このようなわが国農業を 取り巻く状況の下で農業農村整備事業の政策効果を評価 し, 今後の農業農村整備事業のあり方を検討することは, わが国農業を再生し，農村を振興するための重要な課題 である。

政策効果を評価する手法として，事業主体である国が 経済指標, 統計資料, 現地調査により総費用総便益比を 含め多角的に評価し, 学識経験者による審查を経て決定 される事後評価制度がある。したがって事業の効果など は制度的にすでに検証されていると言えるが，今後の農 業農村整備事業のあり方を考える上で必要な受益農家の 具体的受益享受感や，事業実施後の農業農村整備事業に 対する農家認識については十分に明らかとはなっていな い。

農業農村整備事業の評価に関する研究は数多く，たと えば國光は公共事業の経済評価の必要性と費用便益分析 を事後評洒へ適用する場合の改善点を指摘し，固場整備 事業の事業後の効果発現状況を明らかにしている ${ }^{3)} 。$ 伊 藤は集落排水事業の費用便益分析の手法を確立するため, 北海道の集落排水事業完了地区の事業評価を行っている 4)。また矢野らは北海道北東部の町村を対象に農家の土
地改良事業に対する効果や期待の意識調査を行い分析し ている ${ }^{5)}$ このように従来の研究は評価の手法開発や特 定の事業に関する評価を内容とするものが多く, 効果に 対する受益農家の認識を広域的に比較検証した研究は見 当たらない。

このため, 本研究は北海道において実施された国営農 業農村整備事業のうち事後評価を終えた地区の受益農家 を対象に，事業の効果に対する認識や国営事業に対する 考え方などを調査し，受益農家側から見た事業効果の検 証と課題の抽出を目的とする。なお研究の対象は，事業 規模吕大きく基幹的な整備を実施し，また事業の事後評 価に関する資料が比較的長期にわたり公表されている国 営農業農村整備事業とした。

\section{II 研究方法}

北海道における国営農業農村整備事業の公共事業評価 制度では, 平成 13 年度より平成 22 年度まで約 100 地区を 対象として事後評価が実施され，その結果は農林水産省

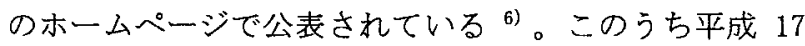
年度からは総費用総便益比が公表され, 平成 22 年度まで 55 地区が評価されている。本研究の調査地区はこの 55 地区から20地区を選定した。これらの地区は母集団であ る 55 地区の事業種別注 2)，営農形態別注3)受益者数割合 を基本に母集団を代表するよう選定した。20地区の受益 者 1,543 名に対して平成 23 年 12 月から平成 24 年 1 月に かけて郵送法によりアンケートを行ない，565名 (36.6\% ）の有効回答を得た（表 1）。

森ら ${ }^{7)}$ は, 平成 17 年度以降の 55 地区の事後評価結果 定総費用総便益比，農業就業者年齢，戸当たり農業所得に ついて分析している。本研究ではこの結果を参考に調查 項目を設定した。具体的には，全地区で総費用総便益比 が 1.0 以上あることを確認したが，その要因を分析する 
表 1 調查対象地区の概要

Table 1 Outline of the project studied

\begin{tabular}{|c|c|c|c|c|}
\hline 亟 染種 别 & 地区と営朁形態 & 受益者数 & 有効回答数 & 回答淬 \\
\hline かんがい排水承業 & $\begin{array}{ll}A & (\text { 水田) } \\
B & (\text { 水田・烟 }) \\
C & \text { (畑) } \\
D & (\text { 畑 })\end{array}$ & $\begin{array}{c}159 \\
57 \\
77 \\
171 \\
\end{array}$ & $\begin{array}{l}47 \\
21 \\
36 \\
59\end{array}$ & $35.1 \%$ \\
\hline 総合農地閒発事業 & 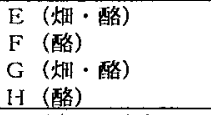 & $\begin{array}{l}63 \\
53 \\
45 \\
58 \\
\end{array}$ & $\begin{array}{l}26 \\
12 \\
20 \\
13\end{array}$ & $32.4 \%$ \\
\hline 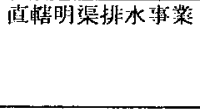 & $\begin{array}{ll}\mathrm{I} & \text { (水田 - 烟) } \\
\mathrm{J} & \text { (畑・酪) } \\
\mathrm{K} & \text { (畑) } \\
\mathrm{L} & (\text { (烟) } \\
\end{array}$ & $\begin{array}{c}35 \\
163 \\
117 \\
90 \\
\end{array}$ & $\begin{array}{l}16 \\
74 \\
54 \\
28\end{array}$ & $42.5 \%$ \\
\hline 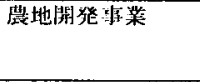 & $\begin{array}{ll}M & (\text { (畑) } \\
N & (\text { (畑・酪) } \\
O & \text { (炏 - 酪) }\end{array}$ & $\begin{array}{l}77 \\
23 \\
12\end{array}$ & $\begin{array}{c}21 \\
9 \\
5\end{array}$ & $31.3 \%$ \\
\hline 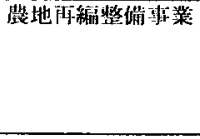 & 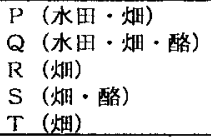 & $\begin{array}{l}110 \\
85 \\
50 \\
72 \\
26 \\
\end{array}$ & $\begin{array}{l}40 \\
22 \\
22 \\
25 \\
15 \\
\end{array}$ & $36.2 \%$ \\
\hline 合 & & 1543 & 565 & $36.6 \%$ \\
\hline
\end{tabular}

注） $\chi^{2}$ 検定により有効回答と受益者には有意な差はなく，回答 者は受益者を代表していると判断された。

ため図 1 に示す「事業効果があったか」を5段階で，ま た図 2 に示す「効果の要因」を質問項目とした。また国 営事業の意義についての農家意識を知るため「国営事業 の必要性」と「必要な理由」を訊ねた。さらに受益地区 の農業就業者のほうが，その存在する市町村全体の農業 就業者の平均年齢より若く，農業所得は高いという結果 を得た。その要因として後継者の有無や事業による経営 面積の増加が考えられ，その関係を分析するため調查し た。

なおアンケートの分析には，エクセル統計 2010 (株式 会社社会情報サービス）を利用した。

\section{IIII 結果}

\section{1 回答者の概要}

回答者の平均年齢は 57.3 歳であり，年齢構成は図 3 のとおりである。回答者の傾向をつかむため，調査地区 が属する市町村の年齢別農業経営者の割合（2010年農林 業センサス ${ }^{8)}$ ) と比較すると，回答者は 60 歳から 64 歳

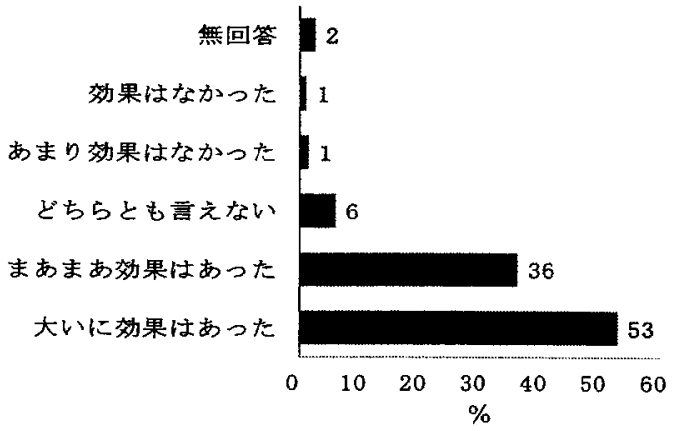

図 1 「事業効果があったか」という問いへの回答 Fig. 1 Answers to the question asking whether the respondent feels benefit from the project

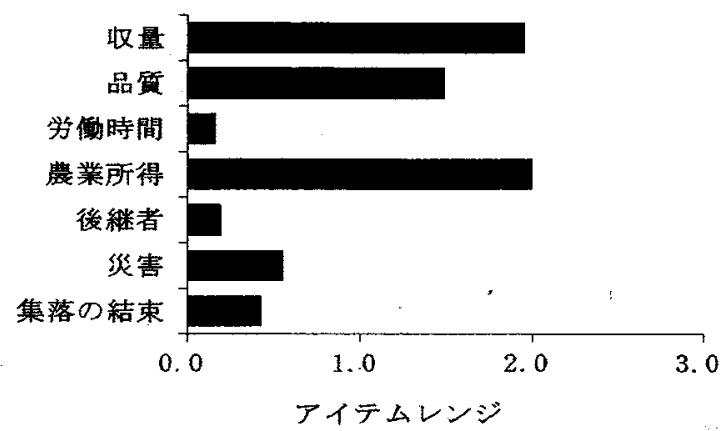

図 2 効果の要因と影響度

Fig. 2 Benefit factors and its effectiveness

が多く，65 歳以上は市町村の $23 \%$ に対して回答者が 17 \%であった。なお，センサスの平均年齢は 57.3 歳と同じ であるが, 両者の年齢構成には有意な差 $(p<0.01)$ が認め られた。

\section{2 事業効果}

事業効果の有無については,「大いに効果あり」から「効 果なし」まで 5 段階の尺度に対して,「まあまあ効果あり」 と「大いに効果あり」をあわせて $89 \%$ が効果ありと回答 した（図 1)。さらに「どちらとも言えない，「あまり効 果なし」を「効果なし」に加えて集計し，「まあまあ効果 あり」，「大いに効果あり」との 3 項目を営農形態別，事 業種別ごとにクロス集計し残差分析した結果，営農形態 別では「水田」,「水田・畑」の「効果なし」と「畑・酷」 の「大いに効果あり」が，事業種別では「かんがい排水」 の「効果なし」と「農地開発」の「まあまあ効果あり」 が特に有意であった（表 2，表 3 ）。

次に効果の内容を「収量」,「品質」,「所得」,「労働時 間」，「災害」，「後継者」，「集落の結束」に区分して，区 分ごとに「増加」，「変わらない」，「減少」など 3 段階の カテゴリーを設けて質問し，効果の有無を目的変数とし て数量化I類により判別分析を行った。図 2 に要因別の 影響度を表わすアイテムレンジを示す。アイテムレンジ は「収量」であれば「増加」から「減少」までの3段階 のカテゴリ一数量の最大值 (0.251) と最小值 (-1.696) の差（1.947）となり，レンジが大きいほど目的変数に与

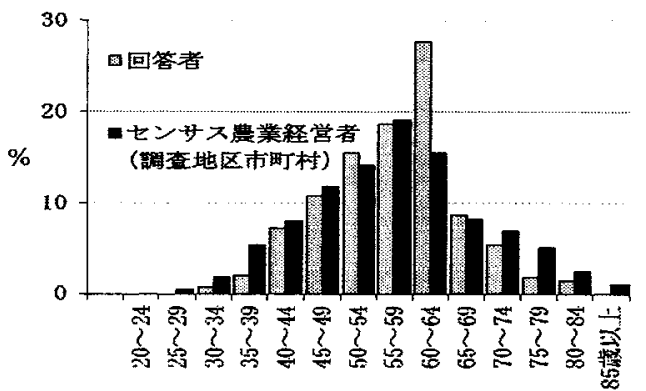

図 3 回答者とセンサス農業経営者の年齢構成 Fig. 3 Differences of age structure between questionnaire of this study and the national census 
表 2 営農形態別効果の有意性

Table 2 Effect significant of each farming type

\begin{tabular}{|c|c|c|c|}
\hline 党農形態 & 効果なし & まあまあ效果あり & 大いに効果あり \\
\hline 全体 & $8.3 \%$ & $37.3 \%$ & $54.5 \%$ \\
\hline 水田 & $+\quad * *$ & n. $s$ & $-\quad * *$ \\
\hline 水田・畑 & $+\quad * *$ & n.s & n. $s$ \\
\hline 水田・畑・酪 & n. $s$ & $\pm *$ & n. $s$ \\
\hline 畑 & $-\quad *$ & n. $s$ & n. $s$ \\
\hline 畑 - 酷 & n. $s$ & - & $+\quad * *$ \\
\hline 酪 & n.s & n.s & n.s \\
\hline
\end{tabular}

注：1）*は 5\%，**は1\%有意，n.sは有意性のないもの。

注：2）全体の割合より大きい(小さい)ものを+（一) で示した。 表 3 事業種別効果の有意性

Table 3 Effect significant of each project

\begin{tabular}{c|c|c|c}
\hline 事業種別 & 効果なし & まあまあ効果あり & 太いに効果あり \\
\hline 全体 & $8.3 \%$ & $37.3 \%$ & $54.5 \%$ \\
\hline かんん゙、排 & $+* *$ & n.s & n.s \\
\hline 総合農地開発 & n.s & n.s & n.s \\
\hline 直轄明渠 & n.s & n.s & n.s \\
\hline 農地開登 & n.s & $+* *$ & $-* *$ \\
\hline 農地再編開発 & n.s & n.s & n.s \\
\hline
\end{tabular}

注 : 1) *は 5\%,**は 1\%有意, n.s は有意性のないもの。

注：2）全体の割合より大きい（小さい）ものを+（一）で示した。

える影響が大きいことを示す。分析の結果，農業所得の 增加, 収量の増加, 品質の向上が事業効果を認識する要 因であり，労働時間の減少や後継者の確保，災害の減少， 集落の結束などは影響が小さい。なお゙サンプルスコアに よる判別的中率は $82 \%$ であった。また所得の増加には収 量の増加と品質向上との多重共線性はなく，それぞれ独 立した項目として取り扱った。

事業種別の効果要因を分析するため, 図 2 の「収量」, 「品質」など7 項目の効果要因ごとに, 図 1 の「効果あり」 から「効果なし」までの5 段階と「増加」,「変わらず」「減 少」などの 3 段階をクロス集計し， $\chi^{2}$ 検定した結果を事 業種別に整理したものを表 4 に示す。この結果，労働時 間について，かんがい排水事業や直轄明渠排水事業は効 果発現の要因として判断できるが，面整備事業である総 合農地開発事業, 農地開発事業, 農地再編整備事業は効果 との有意な関係が認められなかった。また，直轄明渠排 水事業で災害, 後継者の確保に有意な関係があった。

\section{3 国営事業の必要性}

国営事業が必要であると認識する受益農家は $84 \%$ で あった（図 4）。「必要あり」と答えた理由を表 5 の項 目について回答を求め, 主成分分析により解析した $(n=471)$ 。「予算の確実性」，「国が関与することの誇

表 4 事業種別の効果要因との有意性

Table 4 Effect factor significant of each project

\begin{tabular}{c|c|c|c|c|c|c|c}
\hline 事業種別 & 収量 & 品質 & 所得 & 労働時間 & 災害 & 後継者 & 集落の結束 \\
\hline かんがい排水事業 & $* *$ & $* *$ & $* *$ & $* *$ & n.s & n.s & n.s \\
\hline 総合農地留発事業 & $* *$ & $* *$ & $* *$ & n.s & n.s & n.s & n.s \\
\hline 直轄明渠排水事業 & $* *$ & $* *$ & $* *$ & $*$ & $* *$ & $*$ & n.s \\
\hline 農地開發事業 & n.s & $*$ & $* *$ & n.s & n.s & n.s & $* *$ \\
\hline 農地再編開発事業 & $* *$ & $* *$ & $* *$ & n.s & n.s & n.s & n.s \\
\hline
\end{tabular}

注）*は $5 \%$ ，**は1\%有意，n.sは革却できなかったもの。

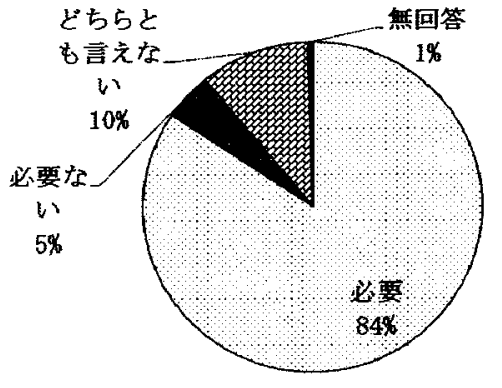

図 4 国営事業の必要性に対する回答

Fig. 4 Answer to the necessity of government-operated project

り」など第 1 成分では「国営事業の信賴性」に関する内 容と判断された。一方，第 2 成分では「負担金が少ない」,

「完了後の支払いが楽」など「国営事業の負担感」と分 類できた（表 5）。なお，この主成分は固有值 1 以上を 使用し，累積寄与率は 46\%であった。また，国営事業が 「必要ない」,「どちらとも言えない」と答えた受益農家 は $15 \%$ と少ないものの，その理由についての主成分分析 $(\mathrm{n}=37)$ では，「技術に対する不信」，「アフターケアに対 する不満」など「信頼性」に関する内容と，「工期が長い」, 「負担金が高い」など「負担感に関する内容であった。 いずれも国営事業で「必要あり」としたグループと同様 の分類となったが，内容は否定的評価であった。事業種 別, 営農形態別に「必要あり」,「不必要」の間の有意差 を $\chi^{2}$ 検定した。その結果, 事業種別では有意な差がなく， 営農形態別では「水田」に不必要が多く,「畑」に必要が 多いという有意な差が得られた。

\section{4 後継者の状況}

後継者の有無により事業効果, 国営事業の必要性など 基盤整備に対する農業者の意識が影響されると考えられ たため，効果の要因として「事業後に後継者ができたか」 またフェイス調查で「後継者の有無」を改めて問い，回 答の整合性を確認する質問項目を設定した。事業後に後 継者が確保されることは前述のように事業効果の大きな 要因とはならなかった。しかし，2010 年農林業センサス の「農業後継者の有無別農家数」9)によれば北海道の後

表 5 必要理由の主成分負荷量

Table 5 Factor loading of necessary reasons

\begin{tabular}{l|r|r}
\hline \multicolumn{1}{c|}{ 変 数 } & 主成分1 & 主成分2 \\
\hline 整備に対する負担金が少ない: & -0.058 & 0.704 \\
支街に信頼がおける & 0.572 & 0.165 \\
国の予算は確实に確保され工期が速い & 0.651 & 0.324 \\
国が関与することで農業に誇りを持つことができる & 0.611 & -0.430 \\
事業完了後に負担金を支払うのは楽である゙注:2) & 0.389 & 0.506 \\
農業政策と連動している & 0.460 & -0.458 \\
完了後のアフターケアが良い & 0.660 & 0.018 \\
\hline
\end{tabular}

注:1) 国営事業は補助率が高く負担金が少ない。

注:2）国営事業では効果の発現する事業完了後に負担金を年毎に償 還する。 


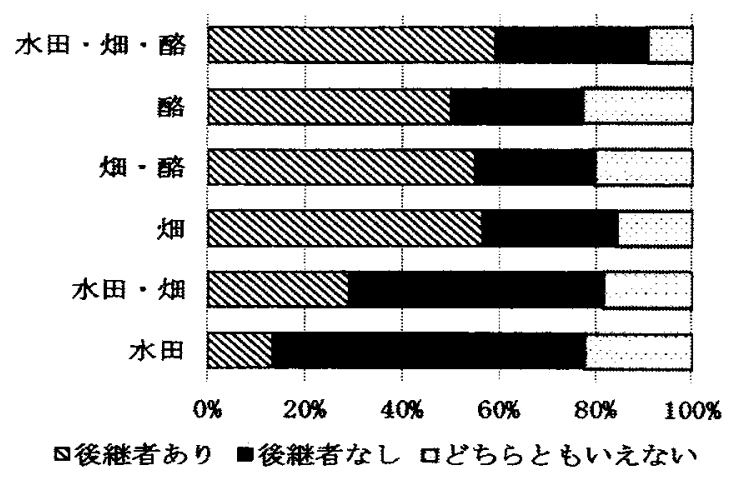

図 5 営農形態別の後継者の割合

Fig. 5 Ratio of successor in each farming type

継者のいる農家数の比率は $24 \%$, 回答者の同比率は $48 \%$ で受益地区内の後継者の比率が高い。さらに，「水田」， 「水田・畑」において後継者が確保されていないのに対し て「水田・畑・酪」，「酪」「畑・酪」，「畑」では後継者の 割合が高い(図 5)。また事業種別と後継者のクロス集計 結果では「かんがい排水事業」で後継者が少なく、「直轄 明渠排水事業」で後継者が多い結果となった。

\section{5 経営農地面積}

森ら〉による事後評価結果の分析では，受益地の戸当 たり農業所得は受益地区を含む関係市町村のそれより大 きかった。この原因は受益地内の戸当たり農地面積が大 きいためと考察している。そこで本研究では，所得增と 面積増の関保を分析するため，事業による面積増加量と， それ以外の離農跡地の購入や借地による面積增加量を調 查し,さらに図 6 に示す離農跡地取得の動機について質 問した。

その結果,面整備事業である農地開発, 総合農地開発， 農地再編整備において「事業による增加」は $31 \%$ ，「離 農跡地の購入による増加」が $56 \%$ であった。また，かん がい排水，直轄明渠を加えた全事業にお打る経営面積の 増加の「離農跡地の購入による増加」が 55\%であり，離 農跡地の購入が経営面積拡大の大きな要因であった。さ らに離農跡地の取得動機を見ると,「自己所有地に近いこ と」が $90 \%$ と大きく，「事業により整備された優良農地 だから」は6\%に過ぎなかった(図 6)。ただし取得した離 農跡地が地区内かどうかの質問に対して $76 \%$ が「地区内 の農地」と答えている。

\section{IV 考察}

\section{1 事業効果}

森”らが行った事後評価結果の分析では，総費用総便 益比が全地区で 1.0 以上あったが，今回の調査でも $89 \%$ の受益者が効果ありと認識していた（図 1)。このことは

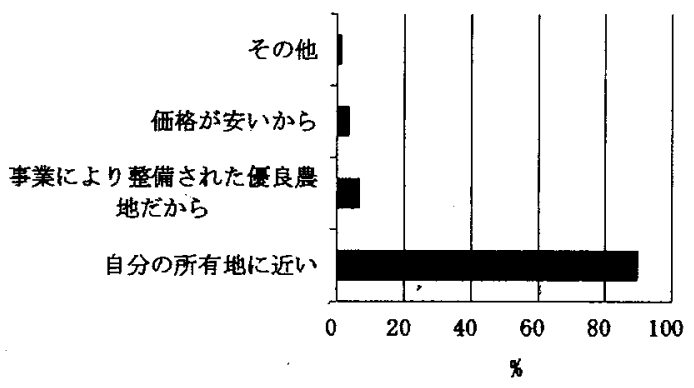

図 6 離農跡地取得の動機

Fig. 6 Incentive of buying farm field

国営事業の各工種の効果を受益者自身が実感しているこ とを示す。また事後評価結果ではかんがい排水事業の総 費用総便益比は他の事業より低かった ${ }^{7)}$ が，今回の調查 でも同様に「効果なし」とした回答者が「かんがい排水 事業」で有意な美を持って多かった（表 3)。営農形態別 でも「水田」で効果なしとの回答が多く（表 2)，水田を 対象とするかんがい排水事業は, 減反政策, 米価の低迷 など外部要因によって所得が減少し効果が堿じられたこ とと, 本来不足する水田用水が事業前から受益地内で調 整されていた結果, 効果が実感されなかったと推測され る。逆に「効果あり」が有意な差を持って多かったのは 「畑・酪」であった（表 2)。とりわけ直轄明渠排水事業 $\mathrm{J}$ 地区では, 排水効果の向上により付加価值の高い野菜 の導入が進み社 れ, 収量, 品質, 所得の増加に結び付いた ことがアンケートの回答内容からも認められた。

効果要因の判別分析の結果（図 2) では, 収量の増加, 所得の向上, 品質の向上が大きな要因であった。質問項 目には「事業後に後継者ができたか」，「洪水被害などの 災害は减少したか子，「区画の拡大，かんがい設備の整備 などにより労働時間は短縮したか」，「事業実施や管理に 伴う集落の結束が強まったか」など，効果の多面性を仮 定した質問も行ったが，効果の要因としては小さかった。

次に, 事業別の効果要因（表 4) では, 労働時間が面 整備事業で効果なしと認識されたが, これは新たな農地 造成による経営面積の挔大が労㗢時間の増加を引き起こ したことによると考えられる。農地再編整備事業は区画 整理が中心の事業であるため学衝時間の短緶が図られて いると考えられるが，今回の調查では農家に効果の認識 がない。この原因は, 今回の調査地区が畑作や酪農地帯 の大規模な畑を主体とした農地再編整備地区であるため 水田の大区画化のような大きな労働時間の短縮が実感で きないことによると考えられる。

一方, 直轄明渠排水事業の効果として災害の減少に有 意な関係があったが，これは排水効果が大きいことを示 
している。なお, 直轄明渠排水事業で後継者確保の効果 が大きいのは，排水整備により新規作目の導入が進み，所 得が増加し後継者の確保が進んだ結果と推測される。農 地開発と集落の結束の有意性については，アンケート結 果だけでは考察できなかった。

このように，事業による効果はそれぞれの事業の持つ 特徴ある工種を的確に反映したものであり，また水田の かんがい排水事業のように米洒の低迷など外的要因も反 映したものであることが受益者の評価から実証できた。

\section{2 国営事業の必要性}

効果に対する認識とともに, 国営事業自体に対する認 識を調查するため,「必要」,「不必要」とその理由について 質問した。「必要」が 84\%と高かった（図 4) が，受益農 家にとっては消極的な意味での必要性，すなわち「あっ たほうがよいと考えた結果とも思われる。ここで重要な ことは, その理由である。主成分分析の結果から（表 5)， 受益者が「国営事業の信頼性」と「低い負担感」を国営事 業の必要な理由としており，国営事業の持つ確実な財政， 高度な技術や高い補助率などの特質を的確にとらえてい る。「不必要」の理由が必要と同様に「信頼性」と「負担感」 に分類されたことも国営事業の評価は「信頼性」と「負 担感」に強く影響されることを裹付けている。また「政 策との連動性」や「国の事業を行うことの誇り」なども 国営事業の「必要性」の要因であるとの回答があり，国 営事業の今後の在り方を考えるうえで重要な知見である。

かんがい排水事業などの事業種別では事業間に有意な 差が見られず, 営農形態別で「水田」に「不必要」が多く，

「畑」に「必要」が多いことは事業効果と同様に「水田」 での効果の実感が小さいことが原因である。工期の長期 化に言及していることからも水田受益者の評価は箃しい ことを示唆している。なお,アフターケアの良し悪しは個 別農家への対応が反映しているものと考えられ，評価が 困難であった。

\section{3 後継者の状況}

効果の要因として「事業後に後継者を確保した」とい う回答は少なく, 後継者の問題と国営事業実施との間に 関連性は認められなかった。森ら ${ }^{7)}$ は事後評価結果の分 析で受益地内の農業就業者の年齢が関係市町村の農業就 業者よりも若く，意欲ある農業者が多いという結果を示 した。本研究での後継者の有無の調查結果でも「後継者 あり」の割合は北海道全体の「後継者あり」の割合の 2 倍あり，受益地区において後継者が確保されていること は確認できたが，受益地区内の農業就業者が相対的に若 いということを検証することはできなかった。

\section{4 経営農地面積}

森ら ${ }^{7)}$ の事後評洒結果の分析では, 受益地内の経営農
地面積の増加は関係市町村の経営農地面積の増加より多 く,それが戸当たり農業所得の増加に結びついていると している。そこで本研究では国営事業による効果を確認 するためアンケート調查を行ったが，面整備事業による 増加はあるものの，その寄与の程度を数值で表すことは できなかった。経営農地面積の増加は離農跡地の購入や 借地によるところが多く，事業実施との関係を実証する ことはできなかっだ。離農跡地取得の動機（図 6）から， 受益者は第一に自己所有地周辺の農地を購入するが, 国 営事業地区はそれを包含する広い受益地を持つため，結 果的に地区内の農地を購入したことになる。

また回答に「とにかく農地がほしいりという意見もあり， かんがい排水事業の水利権のある農地のように明確な付 加価值のある場合を除き，国営事業での整備を意識して 購入しているわけではない。

\section{V おわりに}

本研究では事業の評価を農家の視点で検証した。受益 農家が作物の増収効果, 所得増加効果, 品質向上効果を 評価していること，国営事業について負担金が少ないこ とばかりでなく, 予算の確保, 国の関与, 完了後のアフ ターケア，技術的信頼，そして政策との連動などの「国 営事業の信頼感」があることを評価していることが明ら かとなった。また, 事業別では「直轄明渠排水事業」, 営 農形態別では「畑」などに後継者が多く，事業による排 水効果の向上や畑地かんがいの整備により新規作物が導 入され所得が向上したことがその要因と考えられ，国営 事業の新たな評価が示唆された。一方，米価の低迷や減 反政策の影響を受けた水田地帯の農業者は，かんがい排 水事業に政策との矛盾を感じ否定的見解を持っており， 畑地帯の肯定的見解と対照的な結果となった。

本来政策実現手段である農業農村整備事業は政策と密 接な関連を持って進められているが，政策の変更に即時 に対応できない事業の性格から，農業者の意向と苟䶜を きたすという課題も明らかとなった。

最近の北海道における農業農村整備事業の政策展開と して, 従来の畑作地帯の農地再編整備事業とは異なる水 田の大区画化を目的とした農地再編整備事業が農業者の 要望を受けて数多く実施されている。これは水田地帯の 米価低迷による所得低下の対抗策として水田地帯におい て農業生産法人注 5) を設立し経営規模の拡大と農作業, 農業機械の共同化や農作業の受託による所得の向上に活 路を見出そうとするもので，政策と農業者の意向が一致 した好例としてその成果が期待される。これらの事業の 事後評価を含めた政策効果の検証が引き続き必要である。 
また，「環境への配慮」，「所得補償と基盤整備」，「将来 の基盤整備の必要性」などに対する農業者の認識を明ら かにして，事業制度や実施主体のあり方など多角的な検 討を進め，より効率的な農業農村整備事業の方向性につ いて考究する必要がある。

\section{謝辞}

アンケート調査に当たり協力いただいた国土交通省北 海道開発局農業水産部関係各位に感謝申しげるととも に，真摰な回答をおよせいただいた農業者の皆柡に心か ら感謝申し上げる。

\section{注}

注 1) 例えば「地方分権改革推進法」(平成 18 年 12 月 15 日法律第 111 号）第 5 条には，地方分権改革の推進 に関する国の施策として，国は国が本来果たすべき 役割を重点的に担い，住民に身近な行政はできる限 り地方公共団体に委ねることを基本として，適切な 役割分担をするよう権限委譲の推進を定めている。 注 2）事業種別とは，かんがい排水事業，総合農地開発 事業, 直轄明渠排水事業, 農地開発事業, 農地再編 整備事業など，農林水産省が要綱で定めた事業制度 の名称であり，採択基準，補助率，事業工種が事業 制度ごとに定められている。

注 3）営農形態は,「水田」,「水田・畑」,「畑」,「畑・酪」, 「酷」,「水田・畑・酪」など, 事後評価書に記載さ れている地区別の営農形態を言う。本研究で実施し たアンケートの回答者の営農形態も評価書の営農 形態と変わらないことを確認した。

注 4）直轄明渠排水事業 J 地区（表 1）では，排水の整備 により長芋の導入が可能となり，海外への輸出など 所得の大幅な增加が見られた ${ }^{10)}$ 。

注 5）水田地带の農地再編整備事業 Na 地区 ${ }^{11)}$ では，事 業を契機に二つの生産法人が設立された。

\section{引用文献}

1）農林水産省：都道府県別食料自給率について, 農林水
産省, <http://www.maff.go.jp/j/zyukyu/zikyu_ritu/pdf/ws. $p d f>， 2011$ 年 11 月 16 日, 2012 年 3 月 25 日.

2) 国土交通省北海道開発局: 北海道開発局関係予算概要, 北海道開発局, <http://www.hkd.mlit.go.jp/topics/yosani nfo/h22_yosan/files/h22_tosho.pdf>, 2012 年 2 月 9 日, 2 012 年 3 月 25 日.

3）國光洋二（2008）:『農村公共事業の経済評価』，農林 統計協会，東京。

4）伊藤寛幸（2005）：費用便益分析による農業集落排水 事業の事後評価, 北海道大学大学院農学研究科邦文紀 要, 27 (1), pp. 1-114.

5）矢野健一郎・北村泰介（2008）：AH P 手法の応用に 上る農業農村整備事業の事後評価, 北海道土地改良設 計技術協会報文集，20，pp.43-49.

6）農林水産省：公共事業評価（農業農村整備事業評価）,

農林水産省，<http://www.maff.go.jp/j/nousin/noukei/ind ex.html>，2012 年 4 月 2 日，2012 年 4 月 10 日

7）森繁・山本忠男 - 井上京 - 長澤徹明（2011）：北海道 総合開発計画と土地改良事業の展開と評価，農村計画 学会誌，30（論文特集号)，pp. 327-332

8）農林水産省：2010年世界農林業センサス第 1 巻都道 府県別統計書, 農林水産省, <http://www.e-stat.go.jp/S G1/estat/GL08020103.do?_toGL08020103_\&tclassID=000 001036089 \& cycleCode $=0$ \& requestSender $=$ search $>, 2012$ 年 1 月 31 日，2012年 4 月 1 日.

9）農林水産省：2010 年世界農林業センサス第 2 巻農林 業経営体調査報告書-総括編一, 農林水産省, < http://w ww.e-stat.go.jp/SG1/estat/List.do?bid $=000001034606 \&$ cyc $\mathrm{ode}=0>, 2012$ 年 2 月 29 日, 2012 年 4 月 1 日

10）農林水産省：平成 22 年度完了後評価，農林水産省< http://www.maff.go.jp/j/nousin/noukei/jigyouhyouka/h22ka nryou/pdf/data2i.pdf>, 2011 年 12 月 14 日，2012 年 4 月 13 日

11）菊地誠，濱口大志，安井章二, 辻崎徹（2008）：農業 生産の組織化と今後の展開, 農業農村工学会誌, 76 (1 0), $\mathrm{pp}, 15-19$

\footnotetext{
Summary: In this study, the government-operated agriculture and rural development project in Hokkaido, Japan, has been examined based on the evaluation made by the viewpoint of beneficiary farmers of the project. The consideration for the future projects is also discussed. From the result of the questionnaire, it became clear that the beneficiary farmers are recognizing the effectiveness of the project, such as increase in income, increase in the yield, and quality improvement of the products. The farmers value the project for its low burden charge as well as its coupled correspondence between the measures and the policies. Farmers of paddy field farming and upland farming gave different results in the questionnaire. This difference seems to be a result of the disparity of the agricultural policy in both farming type.

キーワード（Keyword）:農業農村整備事業(agriculture and rural development project)，事後評価(ex-post evaluation), 事業効果 (effectiveness of project)，国営事業(government-operated project), 受益農家(beneficiary farmers)
} 